\title{
Effect of Temperature on Soil Enzyme Acid Phosphatase
}

\author{
J. Aruna Kumari ${ }^{*}$, P.C. Rao ${ }^{2}$, G. Padmaja $^{3}$ and M. Madhavi ${ }^{4}$ \\ ${ }^{1}$ Department of Biochemistry, College of Agriculture, Rajendranagar, PJTSAU, India \\ ${ }^{2}$ Department of Agriculture, PJTSAU, India \\ ${ }^{3}$ Agricultural College, Jagital, India \\ ${ }^{4}$ ACRPP, Weed control, Rajendranagar, India \\ *Corresponding author
}

\section{A B S T R A C T}

Soil enzymes play a major role in mineralization of nitrogen, phosphorus and sulphur. mineralization is the process of transformation of organically bound elements into mineral form which will readily taken up by plants and is crucial to plant nutrition and indirectly plays a role agriculture productivity. The enzyme phosphatase plays an important role in providing the plant its nutrition. In most soils, the organically bound $\mathrm{P}$ - fraction is higher

\begin{tabular}{|c|}
\hline Keywords \\
\hline $\begin{array}{l}\text { Alfisol, Acid } \\
\text { phosphatase, } \\
\text { Temperature, Vertisol, } \\
\text { Climate change and } \\
\text { Productivity }\end{array}$ \\
\hline Article Info \\
\hline $\begin{array}{l}\text { Accepted: } \\
\text { 20 August } 2018 \\
\text { Available Online: } \\
\text { 10 September } 2018\end{array}$ \\
\hline
\end{tabular}
than the inorganic. Phosphorus uptake by plants requires mineralization of the organic $\mathrm{P}$ component by phosphatases to available form. Phosphatases are inducible enzymes that are produced predominantly under conditions of low phosphorus availability. Phosphatases are excreted by plant roots and by microorganisms. Microbial phosphatases dominate in soils. The activity of phosphatase in soil is influenced by the temperature. The abiontic enzymes present in the soil play an important role in catalyzing several important reactions necessary for the life processes of microorganisms in soils and their by stabilizing soil structure, the decomposition of organic wastes, organic matter formation and nutrient cycling. When the temperatures are increased due various changes caused by global warming and other aspects they have a profound influence on soil enzymes and indirectly on agricultural productivity. Every enzyme has its own optimum temperature below the optimum temperature the enzyme activity is less due to inactivation and above the optimum temperature the enzyme activity decreases due to denaturation. Due to increase in temperature the enzymes are denatured and nutrients availability is decreasing and indirectly effecting productivity. To study the effect of temperature on soil enzyme activity four different soils samples were collected and incubation studies were carried out at different temperatures ranging from $20{ }^{\circ} \mathrm{C}$ to $90^{\circ} \mathrm{C}$ with two Alfisols and two Vertisols. The enzyme activity ranged from 9.2 to 297.5 ( $\mu \mathrm{g}$ of 4-nitrophenol $\mathrm{g}^{-1} \mathrm{soil} \mathrm{h}^{-1}$ )

\section{Introduction}

Agriculture is influenced by climate change, temperature being one of the key components. While farmers are often flexible in dealing with weather and by their experience choose highly adaptive varieties to the local climate and in the soils of arid and semi-arid tropics, the soil available nitrogen is grossly inadequate for sustainable agriculture unless it 
is replenished with the mineralization of organic nitrogen. These enzymes play key roles in overall process of organic matter decomposition and organic nitrogen in soil system which are important reactions necessary for the live processes of microorganisms in soils and stabilization of soil structure decomposition of organic waste, organic matter formation and nutrient cycling (Dick et al., 1994). During the decomposition of organic matter these enzymes are constantly synthesized, accumulated, inactivated and decomposed in soils, hence they play an important role in Agriculture (Tabatabai, 1994; Dick, 1997 and Vandana 2012) soil enzymes have potential to provide unique interactive biological assessments of soils because of their relationship to soil biology ease of measurement and rapid response to change in soil management (Dora et al., 2008).

Among the different facets of soil enzymes the in situ behaviour of soil enzymes in heterogeneous environment of the soil system in respect of their thermal sensitivities, $\mathrm{pH}$ effects, kinetics and moisture effects are of prime importance. Hence the present investigation was designed for studying the effect of temperature on soil enzyme acid phosphatase activity.

\section{Materials and Methods}

The procedure of Tabatabai and Bremner (1969) and Eivazi and Tabatabai (1977) were adopted for the assay of acid phosphatases activity in soils. Two Alfisols and Vertisols soil samples were taken for the study

Modified Universal Buffer (MUB) Stock: The stock of MUB was prepared by mixing $12.1 \mathrm{~g}$ of Tris (hydroxymethyl) aminomethane (THAM), $11.6 \mathrm{~g}$ of maleic acid, $14 \mathrm{~g}$ of citric acid and $6.3 \mathrm{~g}$ of boric acid in $488 \mathrm{ml}$ of $1 \mathrm{~N}$ sodium hydroxide and the solution was diluted to 1 litre with distilled water. Modified Universal Buffer ( $\mathrm{pH}$ 6.5): $200 \mathrm{ml}$ of MUB stock was transferred to 1 litre beaker and kept on a magnetic stirrer and the $\mathrm{pH}$ of the solution was adjusted to 6.5 with $0.1 \mathrm{~N} \mathrm{HCl}$ and volume was made up to 1 litre with distilled water.

Modified Universal Buffer (pH 11): $200 \mathrm{ml}$ of MUB stock was transferred to 1 litre beaker and kept on a magnetic stirrer and the $\mathrm{pH}$ of the solution was adjusted to 11 with $0.1 \mathrm{~N}$ $\mathrm{NaOH}$ and volume was made up to 1 litre with distilled water. The MUB buffer was wrapped with carbon paper and stored in a refrigerator.

P-nitrophenyl phosphate solution $(0.025 \mathrm{M})$ : This was prepared by dissolving $0.420 \mathrm{~g}$ of disodium salt of p-nitrophenyl phosphate in $40 \mathrm{ml}$ of MUB pH 6.5 (for assay of acid phosphatase) and $\mathrm{pH} 11$ (for assay of alkaline phosphatase) and the solution was diluted to $50 \mathrm{ml}$ with MUB of the same $\mathrm{pH}$. The solution was wrapped with carbon paper and stored in a refrigerator.

Calcium chloride $(0.5 \mathrm{M})$ : This was prepared by dissolving $73.5 \mathrm{~g}$ of $\mathrm{CaCl}_{2} \cdot 2 \mathrm{H}_{2} \mathrm{O}$ in distilled water and made up to 1 litre.

Sodium hydroxide $(0.5 \mathrm{M}): 20 \mathrm{~g}$ of sodium hydroxide was dissolved in $700 \mathrm{ml}$ of distilled water and diluted to 1 litre with water.

Standard p-nitrophenol solution: Primary stock solution of $1000 \mu \mathrm{g} \mathrm{ml} \mathrm{m}^{-1}$ of $\mathrm{p}$ nitrophenol was prepared by dissolving $1 \mathrm{~g}$ of p-nitrophenol in distilled water and made up to 1 litre. From this, secondary stock of 100 $\mu \mathrm{g} \mathrm{ml} \mathrm{m}^{-1}$ and $20 \mu \mathrm{g} \mathrm{ml} \mathrm{m}^{-1}$ solutions were prepared. Working standards of $1,2,3,4,5,6$, $7,8,9$ and $10 \mu \mathrm{g} \mathrm{ml}^{-1}$ were prepared from 20 $\mu \mathrm{g} \mathrm{ml}^{-1}$ stock and the absorbance of these standards were recorded at $420 \mathrm{~nm}$ in spectrophotometer. This was used for the standard curve. 


\section{Procedure}

To $1 \mathrm{~g}$ of soil sample taken in glass tubes, 4 $\mathrm{ml}$ of modified universal buffer $\mathrm{pH} 6.5$ (for assay of acid phosphatase) and $\mathrm{pH} 11$ (for assay of alkaline phosphatase) was added followed by addition of $1 \mathrm{ml}$ of 4-nitrophenyl phosphate solution. The glass tubes were swirled for few seconds to mix the contents, stoppered and incubated for one hour at $37 \pm$ $0.5^{\circ} \mathrm{C}$ in BOD incubator. To these, $1 \mathrm{ml}$ of $0.5 \mathrm{M} \mathrm{CaCl}_{2}$ was added followed by addition of $4 \mathrm{ml}$ of $0.5 \mathrm{M} \mathrm{NaOH}$ to deactivate the enzyme and to extract the 4-nitrophenol liberated. The glass tubes were swirled and the soil suspension was filtered through Whatman No. 42 filter paper. The absorbance of yellow color of 4-nitrophenol liberated due to hydrolysis of the substrate by phosphomonoesterases was measured at 420 $\mathrm{nm}$. Controls were run simultaneously following the same procedure except adding 1 $\mathrm{ml}$ of 4-nitrophenyl phosphate after the addition of $1 \mathrm{ml}$ of $0.5 \mathrm{M} \mathrm{CaCl}_{2}$ and $4 \mathrm{ml}$ of $0.5 \mathrm{M} \mathrm{NaOH}$. Corrections were made for control / blank values

\section{Results and Discussion}

The results regarding to the effect of temperature on soil Acid phosphatases activities are depicted graphically in Figure 1. Acid phosphatases activity of all soils used in the study increased with increase in temperature from $20-70^{\circ} \mathrm{C}$ and then activity decreased slowly till $90^{\circ} \mathrm{C}$ and rapidly decreased with further increase in temperature to $90^{\circ} \mathrm{C}$. Denaturation occurred beyond $70{ }^{\circ} \mathrm{C}$. for the present study both Alfisols and Vertisols were taken higher activity was observed in Alfisols, the range observed in different soils is as follows in Vertisol I was 11.3 ( $\mu \mathrm{g}$ of 4-nitrophenol $\mathrm{g}^{-1}$ soil $\mathrm{h}^{-1}$ at $20{ }^{\circ} \mathrm{C}$ and increased to 24.1 $\mu \mathrm{g}$ of 4-nitrophenol $\mathrm{g}^{-1}$ soil $\mathrm{h}^{-1}$ at $30^{\circ} \mathrm{C}$ and further increased to 52.1 $\mu \mathrm{g}$ of 4-nitrophenol $\mathrm{g}^{-1}$ soil $\mathrm{h}^{-1}$ at $40{ }^{\circ} \mathrm{C}$ and further increased to $101.8 \mu \mathrm{g}$ of 4-nitrophenol $\mathrm{g}^{-1}$ soil $\mathrm{h}^{-1}$ at $50{ }^{\circ} \mathrm{C}$ and further increased to $189.3 \mu \mathrm{g}$ of 4-nitrophenol $\mathrm{g}^{-1}$ soil $\mathrm{h}^{-1}$ at $60{ }^{\circ} \mathrm{C}$ and further increased to $297.5 \mu \mathrm{g}$ of 4 nitrophenol $\mathrm{g}^{-1}$ soil $\mathrm{h}^{-1} 70{ }^{\circ} \mathrm{C}$ and then when the temperature is increased beyond their optimum temperature its activity decreased to $152.4 \mu \mathrm{g}$ of 4-nitrophenol $\mathrm{g}^{-1}$ soil $\mathrm{h}^{-1}$ at $80{ }^{\circ} \mathrm{C}$ and further decreased to $63 \mu \mathrm{g}$ of 4 nitrophenol $\mathrm{g}^{-1}$ soil $\mathrm{h}^{-1}$ at $90^{\circ} \mathrm{C}$ and in Vertisol II, the range of enzyme activity was as follows was $9.2\left(\mu \mathrm{g}\right.$ of 4-nitrophenol $\mathrm{g}^{-1}$ soil h$^{-1}$ at 20 ${ }^{\circ} \mathrm{C}$ and increased to $22.8 \mu \mathrm{g}$ of 4-nitrophenol $\mathrm{g}^{-1}$ soil $\mathrm{h}^{-1}$ at $30{ }^{\circ} \mathrm{C}$ and further increased to $51.7 \mu \mathrm{g}$ of 4-nitrophenol $\mathrm{g}^{-1}$ soil $\mathrm{h}^{-1}$ at $40{ }^{\circ} \mathrm{C}$ and further increased to $98.8 \mu \mathrm{g}$ of $4-$ nitrophenol $\mathrm{g}^{-1}$ soil $\mathrm{h}^{-1}$ at $50{ }^{\circ} \mathrm{C}$ and further increased to $176.3 \mu \mathrm{g}$ of 4-nitrophenol g ${ }^{-1}$ soil $\mathrm{h}^{-1}$ at $60{ }^{\circ} \mathrm{C}$ and further increased to $258.2 \mu \mathrm{g}$ of 4-nitrophenol $\mathrm{g}^{-1}$ soil $\mathrm{h}^{-1} 70{ }^{\circ} \mathrm{C}$ and then when the temperature is increased beyond their optimum temperature its activity decreased to $137.7 \mu \mathrm{g}$ of 4-nitrophenol $\mathrm{g}^{-1}$ soil $\mathrm{h}^{-1}$ at $80{ }^{\circ} \mathrm{C}$ and further decreased to $54.2 \mu \mathrm{g}$ of 4-nitrophenol $\mathrm{g}^{-1}$ soil $\mathrm{h}^{-1}$ at $90^{\circ} \mathrm{C}$. In case of Alfisol I it was observed that the enzyme activity increased as follows was 12.5 ( $\mu \mathrm{g}$ of 4-nitrophenol $\mathrm{g}^{-1}$ soil $\mathrm{h}^{-1}$ at $20{ }^{\circ} \mathrm{C}$ and increased to $26.9\left(\mu \mathrm{g}\right.$ of 4-nitrophenol $\mathrm{g}^{-1}$ soil $\mathrm{h}^{-1}$ at $30^{\circ} \mathrm{C}$ and further increased to $60.4 \mu \mathrm{g}$ of 4-nitrophenol g ${ }^{-1}$ soil $\mathrm{h}^{-1}$ at $40{ }^{\circ} \mathrm{C}$ and further increased to $133.5 \mu \mathrm{g}$ of 4-nitrophenol g ${ }^{-1}$ soil $\mathrm{h}^{-1}$ at $50{ }^{\circ} \mathrm{C}$ and further increased to $227.6 \mu \mathrm{g}$ of 4-nitrophenol $\mathrm{g}^{-1}$ soil $\mathrm{h}^{-1}$ at $60{ }^{\circ} \mathrm{C}$ and further increased to $445.7 \mu \mathrm{g}$ of 4-nitrophenol $\mathrm{g}^{-1} \quad$ soil $\mathrm{h}^{-1} \quad 70{ }^{\circ} \mathrm{C}$ and then when the temperature is increased beyond their optimum temperature its activity decreased to $202.5 \mu \mathrm{g}$ of 4-nitrophenol $\mathrm{g}^{-1}$ soil $\mathrm{h}^{-1}$ at $80{ }^{\circ} \mathrm{C}$ and further decreased to $90.4 \mu \mathrm{g}$ of 4 nitrophenol $\mathrm{g}^{-1}$ soil $\mathrm{h}^{-1}$ at $90{ }^{\circ} \mathrm{C}$ and in Alfisol II, the range of enzyme activity was as follows was $14.2\left(\mu \mathrm{g}\right.$ of 4-nitrophenol $\mathrm{g}^{-1}$ soil $^{-1}$ at 20 ${ }^{\circ} \mathrm{C}$ and increased to $29.7 \mu \mathrm{g}$ of 4-nitrophenol $\mathrm{g}^{-1}$ soil $\mathrm{h}^{-1}$ at $30{ }^{\circ} \mathrm{C}$ and further increased to $77.8 \mu \mathrm{g}$ of 4-nitrophenol $\mathrm{g}^{-1}$ soil $\mathrm{h}^{-1}$ at $40{ }^{\circ} \mathrm{C}$ 
and further increased to $152.2 \mu \mathrm{g}$ of 4nitrophenol $\mathrm{g}^{-1}$ soil $\mathrm{h}^{-1}$ at $50{ }^{\circ} \mathrm{C}$ and further increased to $269.2 \mu \mathrm{g}$ of 4-nitrophenol $\mathrm{g}^{-1}$ soil $\mathrm{h}^{-1}$ at $60{ }^{\circ} \mathrm{C}$ and further increased to $503.5 \mu \mathrm{g}$ of 4-nitrophenol $\mathrm{g}^{-1}$ soil $\mathrm{h}^{-1} 70{ }^{\circ} \mathrm{C}$ and then when the temperature is increased beyond their optimum temperature its activity decreased to $260.1 \mu \mathrm{g}$ of 4-nitrophenol $\mathrm{g}^{-1}$ soil $\mathrm{h}^{-1}$ at $80{ }^{\circ} \mathrm{C}$ and further decreased to $\mu \mathrm{g}$ of 4 nitrophenol $\mathrm{g}^{-1}$ soil $\mathrm{h}^{-1}$ at $90{ }^{\circ} \mathrm{C}$, negligible increased was observed in case of activity because the thermal stability of the enzyme was completely lost. the temperature coefficient of the enzyme was calculated.

The results pertaining to temperature coefficient were given in the Table 1 . Temperature coefficient values $\left(\mathrm{Q}_{10}\right)$ were calculated in the temperature range of 20 to $90^{\circ} \mathrm{C}$. These values depend on the type of soil which varied from 0.4 to 2.2 in case of Vertisol I and 0.4 to 2.5 in case of Vertisol II in Alfisol a slight higher temperature Coefficient was observed i.e., 0.4 to 2.2 in Alfisol I and 0.6 to 2.6 in case of Alfisol II.

Temperature has a profound effect and controls soil enzyme activities, changing enzyme kinetics and stability, substrate affinity and enzyme production because it can influence the size and activity of microbial biomass. Acid phosphatase activity of soils increased with temperature from $20^{\circ} \mathrm{C}$ to $70^{\circ} \mathrm{C}$ and decreased constantly with further increase in temperature to $90^{\circ} \mathrm{C}$ (Rao, 1989; Srinivas, 1993 and Vandana, 2012). The temperature dependence of soil hydrolase activities was described by Arrhenius equation (Cepeda et al., 2007). They measured the $\mathrm{Q}_{10}$ of nine different enzymes in three different soils and found that the $\mathrm{Q}_{10}$ at $20^{\circ} \mathrm{C}$ exceeded 2.0 only for B-glucosidase in one of the soils. All other soil enzymes in that study had a $\mathrm{Q}_{10}$ closer to 1.5 , corresponding to an Ea of $0.3 \mathrm{eV}$.

Fig.1 Effect of temperature on soil acid phosphatase activity

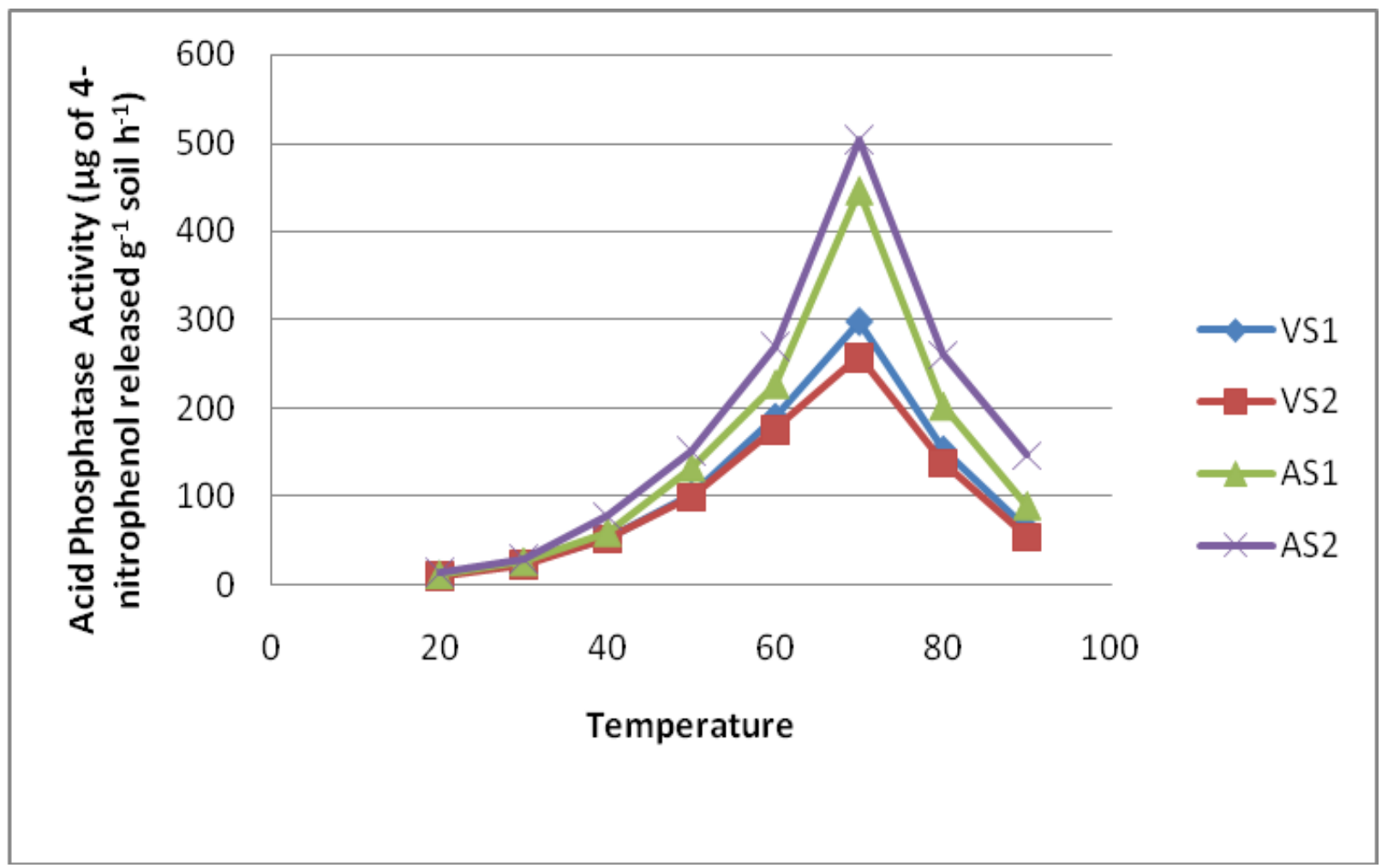


Table.1 Temperature coefficient values $\left(\mathrm{Q}_{10}\right)$ acid phosphatase

\begin{tabular}{|c|c|c|c|c|}
\hline $\begin{array}{c}\text { Temperature range } \\
\left({ }^{\circ} \mathbf{C}\right)\end{array}$ & Temperature Coefficient values $\left(\mathbf{Q}_{\mathbf{1 0}}\right)$ acid & phosphatase \\
\hline $\mathbf{2 0 - 3 0}$ & VS1 & VS2 & AS1 & AS2 \\
\hline $\mathbf{3 0 - 4 0}$ & 2.1 & 2.5 & 2.2 & 2.1 \\
\hline $\mathbf{4 0 - 5 0}$ & 2.2 & 2.3 & 2.2 & 2.6 \\
\hline $\mathbf{5 0 - 6 0}$ & 2.0 & 1.9 & 2.2 & 2.0 \\
\hline $\mathbf{6 0 - 7 0}$ & 1.9 & 1.8 & 1.7 & 1.8 \\
\hline $\mathbf{7 0 - 8 0}$ & 1.6 & 1.5 & 2.0 & 1.9 \\
\hline $\mathbf{8 0 - 9 0}$ & 0.5 & 0.5 & 0.5 & 0.5 \\
\hline & 0.4 & 0.4 & 0.4 & 0.6 \\
\hline
\end{tabular}

The activity of any chemical reaction increases with temperature, for every $10^{\circ} \mathrm{C}$ rise in temperature the rate of the reaction approximately increase by two folds. The rate of enzyme catalyzed reaction increases as the temperature increases until optimum temperature is reached above which the rate begins to decrease because of denaturation of enzyme. The same pattern has been observed in soil enzymes by a number of investigators except the fact that the temperature over which the soil enzymes retain their stability is much higher than that for the free enzymes. This is attributed to the stability effect due to the immobilization of the soil enzymes on soil particulate matter. Activation energies are parameters that mechanistically link enzyme kinetics and temperature responses through the Arrhenius function. Enzyme catalyzed reactions generally show lower activation energies than uncatalyzed reactions, so the temperature sensitivity of the abiotic reactions may be higher (Tabatabai, 1982). Several studies have demonstrated that the temperature sensitivity of extracellular enzymes changes seasonally (Fenner et al., 2005; Koch et al., 2007; Trasar-Cepeda et al., 1988 and Wallenstein et al., 2009).

It is know that the temperature needed to deactivate enzymes in soils is about $10{ }^{\circ} \mathrm{C}$ higher than the temperature needed to inactivate the same enzyme in absence of soil. This has been generally attributed to the immobilization of soil enzymes on soil colloids and cell debris (Tabatabai, 1982; Srinivas, 1993; Raman and Reddy, 1998; Srinivas and Raman, 2000 and Vandana 2012). Changes in temperature not only effect the enzyme production but also effect enzyme degradation rates in the environments. Biological responses include changes in enzyme production rates with shifts in microbial population and composition. The variation in these values may be due to heterogeneity in composition and the state of enzymes at temperature above $40^{\circ} \mathrm{C}$. When the Q10 values were less than 1 which indicates the deactivation of the enzymes set in at that temperature. Recent increases in climate variability may have affected crop yields in countries across Europe since around the mid-1980s (Porter \& Semenov 2005) causing higher inter-annual variability in wheat yields. This study suggested that such changes in annual yield variability would make wheat a high-risk crop in Spain. Even mid-latitude crops could suffer at very high temperatures in the absence of adaptation. In 1972, extremely high summer averaged temperature in the former Soviet Union (USSR) contributed to widespread disruptions in world cereal markets and food security (Battisti and Naylor, 2009).

Temperature has a profound impact on soil enzyme acid phosphatase activity and it influence the biogeochemical cycles in the soil. 


\section{References}

Battisti D. S., Naylor R. L. 2009 Historical warnings of future food insecurity with unprecedented seasonal heat. Science 323, 240-244. (doi:10.1126/science.1164363).

Cepeda, M.C.T and Sotres, F.G. 1988. Kinetics of acid phosphatase activity in various soils of Galicia. Soil Biology and Biochemistry. 20(3): 275 -280

Dick, R.P. 1994. Soil enzyme activities as indicator of soil quality. In J.V. Doran, D.C. Coleman, D.F. Bezdicek and V.A. Stewart (eds.) - Defining Soil Quality for Sustainable Environment, Soil Science Society of America, American Society of Agriculture, Madison. 107 124.

Dick, R.P. 1997. Soil enzyme activities as integrative indicators of soil health. In C.E. Pankhurst, B.M. Doube and V.V.S.R. Gupta (eds.) - Biological Indicators of Soil Health, CAB International, Wellingford. $121-156$

Dora, A.S., Domuta, C., Ciobanu, C and Sandor, M. 2008. Field management effects on soil enzyme activities. Romanian Agricultural Research. 25: 61-68.

Eivazi, F and Tabatabai, M.A. 1977. Phosphatases in soils. Soil Biology and Biochemistry. 9: 167-172.

Fenner N, Freeman C, Reynolds B 2005 Observations of a seasonally shifting thermal optimum in peatland carboncycling processes; implications for the global carbon cycle and soil enzyme methodologies. Soil Biology and Biochemistry 37:1814-1821

Koch, O., Tscherko, D., Kandeler, E., 2007. Temperature sensitivity of microbial respiration, nitrogen mineralization, and potential soil EAs in organic alpine soils. Global Biogeochemistry Cycles 21, 1-11.
Porter J. R., Semenov M. A. 2005Crop responses to climatic variation. Phil. Trans. R. Soc. B 360, 2021-2035]

Raman S and Reddy M.S.R.L 1998 kinetics and activation of L-asparaginase in Alfisols and Vertisols. Journal of Indian Society of Soil science 46 (3) 367-370

Rao, S.V. 1989. Distribution, Kinetics and some interactions of urease and phosphatases in soils. Ph.D. Thesis. Acharya N G Ranga Agricultural University, Hyderabad.

Srinivas, D. 1993. Phosphomonoesterase activity in some soils of Andhra Pradesh. Distribution, kinetics and variation due to plant cover, pesticide application and submergence. Ph.D. Thesis. Acharya N G Ranga Agricultural University, Hyderabad.

Srinivas, D., Raman, S and Rao, P. C. 2000. Influence of plant cover on acid and alkaline phosphatase activity in two soils of Andhra Pradesh. The Journal of Research, ANGRAU. 28(4): 40-47.

Tabatabai, M.A and Bremner, J.M. 1969. Use of P-nitrophenyl phosphate for assay of soil phosphatase activity. Soil Biology and Biochemistry. 1: 301-307

Tabatabai, M.A. 1982. In A.L. Page (eds.) Methods of Soil Analysis, Part 2, Soil Enzymes, American Society of Agronomy Madison. 903 - 948.

Tabatabai, M.A. 1994. Microbiological and biochemical properties. In R.W. Weaver, J.S. Angle and P.S. Bottomley (eds.) - Methods of Soil Analysis, Part 2, Soil Enzymes, Soil Science Society, Society of America Madison. 775 - 833

Trasar-Cepeda C., Gil-Sotres F., Leiros M. C. 2007. Thermodynamic parameters of enzymes in grassland soils from Galicia, NW Spain. Soil Biology and Biochemistry 39, 311-319 10.1016/j.soilbio.2006.08.002.

Vandana, J.L. 2012. Urease and phosphomonoesterase activities in soil - 
their distribution, kinetics and influence of management practices on their activities. Ph.D. Thesis. Acharya N G Ranga Agricultural University, Hyderabad.
Wallenstein MD, Mcmahon SK, Schimel JP 2009 Seasonal variation in enzyme activities and temperature sensitivities in Arctic tundra soils. Global Change Biology, 15, 1631-1639.

\section{How to cite this article:}

Aruna Kumari, J., P.C. Rao, G. Padmaja and Madhavi, M. 2018. Effect of Temperature on Soil Enzyme Acid Phosphatase. Int.J.Curr.Microbiol.App.Sci. 7(09): 2830-2845. doi: https://doi.org/10.20546/ijcmas.2018.709.352 